\title{
Fossil evidence reveals how plants responded to cooling during the Cretaceous-Paleogene transition
}

\author{
Yi-Ming Cui ${ }^{1,3 \dagger}$, Wei Wang ${ }^{1,4 \dagger}$, David K. Ferguson ${ }^{2}$, Jian Yang ${ }^{1,4^{*}}$ and Yu-Fei Wang ${ }^{1,4^{*}}$ (D)
}

\begin{abstract}
Background: Around the Cretaceous-Paleogene (K-Pg) boundary, an obvious global cooling occurred, which resulted in dramatic changes in terrestrial ecosystems and the evolutionary trends of numerous organisms. However, how plant lineages responded to the cooling has remained unknown until now. Between ca. 70-60 Ma Mesocyparis Mclver \& Basinger (Cupressaceae), an extinct conifer genus, was distributed from eastern Asia to western North America and provides an excellent opportunity to solve this riddle.

Results: Here we report a new species, Mesocyparis sinica from the early Paleocene of Jiayin, Heilongjiang, northeastern China. By integrating lines of evidence from phylogeny and comparative morphology of Mesocyparis, we found that during ca.70-60 Ma, the size of seed cone of Mesocyparis more than doubled, probably driven by the cooling during the K-Pg transition, which might be an effective adaptation for seed dispersal by animals. More importantly, we discovered that the northern limit of this genus, as well as those of two other arboreal taxa Metasequoia Miki ex Hu et Cheng (gymnosperm) and Nordenskioldia Heer (angiosperm), migrated ca.4- $5^{\circ}$ southward in paleolatitude during this time interval.
\end{abstract}

Conclusions: Our results suggest that the cooling during the K-Pg transition may have been responsible for the increase in size of the seed cone of Mesocyparis and have driven the migration of plants southwards.

Keywords: Adaptation, Climate change, K-Pg transition, Fossil plant, Morphology, Mesocyparis

\section{Background}

The cooling from the Maastrichtian to the Paleocene that occurred during the Cretaceous-Paleogene (K-Pg) transition (ca. 70-60 Ma), has been recorded by land plant leaf data [1] and marine oxygen isotope records [2]. These dramatic environmental and climate changes [3-5] altered the composition of terrestrial ecosystems and the evolutionary trends of numerous organisms. Examples include the extinction of non-avian dinosaurs and the rise of mammals, the decline of gymnosperms, and the upsurge of angiosperms [6-8]. Some zoological cases indicated how animal taxa changed their morphological features during the K-Pg transition [8-10]. For instance, a previous study found that the maximum body

\footnotetext{
* Correspondence: yangjian@ibcas.ac.cn; wangyf@ibcas.ac.cn

${ }^{\dagger}$ Yi-Ming Cui and Wei Wang contributed equally to this work.

'State Key Laboratory of Systematic and Evolutionary Botany, Institute of

Botany, Chinese Academy of Sciences, Beijing 100093, China

Full list of author information is available at the end of the article
}

size and dental complexity disparity of multituberculate mammals across the K-Pg boundary was associated with dietary expansion [8]. On the other hand, botanical evidence revealed regional vegetation change during this time interval $[11,12]$ and provided estimates of paleotemperature in both hemispheres [2, 12-14]. Leaf physiognomic analysis showed that the $13^{\circ} \mathrm{C}$ mean annual temperature isotherm (mesothermal-microthemal boundary) of high latitudinal western North America moved southwards from ca. $65-75^{\circ} \mathrm{N}$ in the Maastrichtian to ca. $55^{\circ} \mathrm{N}$ in the Danian $[15,16]$. Besides, a study focused on the range changes of Metasequoia around the world since the Late Cretaceous has shown the knowledge of the distributional changes of this genus across the K-Pg transition [17]. Nevertheless, it has remained relatively unknown how specific plant taxa responded to the cooling during the K-Pg transition.

The extinct genus Mesocyparis McIver \& Basinger (Cupressaceae) was distributed in eastern Asia and

(c) The Author(s). 2019 Open Access This article is distributed under the terms of the Creative Commons Attribution 4.0 International License (http://creativecommons.org/licenses/by/4.0/), which permits unrestricted use, distribution, and 
western North America from the Late Cretaceous to the Paleocene, ca. 70-60 Ma [18-22]. Here, we report new fossil material of this genus from the upper part of the Wuyun Formation, Jiayin County, Heilongjiang Province. The new Mesocyparis fossils from Northeast China, together with the other four species of this genus in the Northern Hemisphere, provide us with an opportunity to evaluate adaptions within the genus.

\section{Results}

\section{Systematics}

Order: Coniferales.

Family: Cupressaceae.

Subfamily: Cupressoideae.

Genus: Mesocyparis McIver et Basinger.

Species: Mesocyparis sinica Y. M. Cui, W. Wang, D. K. Ferguson, J. Yang et Y. F. Wang, sp. nov.

Diagnosis: Seed cones ovate to orbicular, borne in opposite pairs (Fig. 1a and Fig.2a). Cone scales 4 in number, woody, obovate to ovate, decussate, approximately equal in size (Fig. 1b, c and Fig. 2b). Umbo near apex of scale, leaflike, erect, with apex tapered (Fig. 1b, c: arrow 2, 2a and $2 \mathrm{~b}$ ). Branches pinnate and opposite, forming flat frond-like sprays (Fig. 1d). Leaves on both vegetative and fertile shoots decussate, scaly and dimorphic with facial and lateral leaves (Fig. 1a, d, Fig. 2a and c).

Holotype: compression fertile shoot with two mature seed cones and two immature seed cones, Palaeobotanical Museum of China, Institute of Botany, Chinese Academy of Sciences (IBCAS), specimen no. WY0801 (Fig. 1)a, b and c.
Etymology: The specific name, sinica, refers to the fossil discovery in China.

Type locality: Wuyun coalmine of Jiayin County, Heilongjiang Province, NE China $\left(49^{\circ} 14^{\prime} \mathrm{N}, 129^{\circ} 28^{\prime} \mathrm{E}\right.$; Fig. 3).

Horizon and age: Wuyun Formation, Danian, Paleocene.

Description: Seed cones borne in opposite pairs, ovate, $4.4-5.2 \mathrm{~mm}$ long, $4.0-5.1 \mathrm{~mm}$ wide (Fig. 1a). Bracts 4 in number, woody, decussate, obovate to ovate, $3.7-4.3 \mathrm{~mm}$ long, $2.8-3.1 \mathrm{~mm}$ wide, and sizes of upper pair and basal pair nearly identical (Fig. 1b and c). Umbo leaflike, erect, at top of scale, with apex acuminate (Fig. 1b and c: arrow 2). Pair of immature seed cones arising from axis of fertile branch measure, $1.4-1.5 \mathrm{~mm}$ long, $0.9-1.3 \mathrm{~mm}$ wide (Fig. 1a: arrow 1). Immature cone scales peltate, $0.7-1.5 \mathrm{~mm}$ long, $0.8-0.9 \mathrm{~mm}$ wide, apex abrupt to blunt.

Fertile shoots flattened, leaves decussate and dimorphic, facial and lateral leaves morphologically different (Fig. 1a). Facial leaves triangular to rhombic, $0.9-2.7 \mathrm{~mm}$ long, 0.7-1.2 mm wide, thickened along midrib. Tips of leaves are acute to blunt, rising above basal part of subsequent leaves. Lateral leaves folded, falcate to triangular, 1.2-2.2 $\mathrm{mm}$ long, $0.4-0.8 \mathrm{~mm}$ wide, apex acute, rising above basal part of subsequent lateral leaves (Fig. 1a).

Branching pinnate, flattened, branchlets plagiotropic, borne in opposite pairs, forming flat frond-like sprays, about $3.2 \mathrm{~cm}$ long. Basal pair of facial leaves arising from the axils of branch lateral leaves. Branchlets on same side parallel, 1.9-2.8 mm apart (Fig. 1d). Scale-like leaves dimorphic, facial leaves adpressed, lateral leaves folded along midrib.

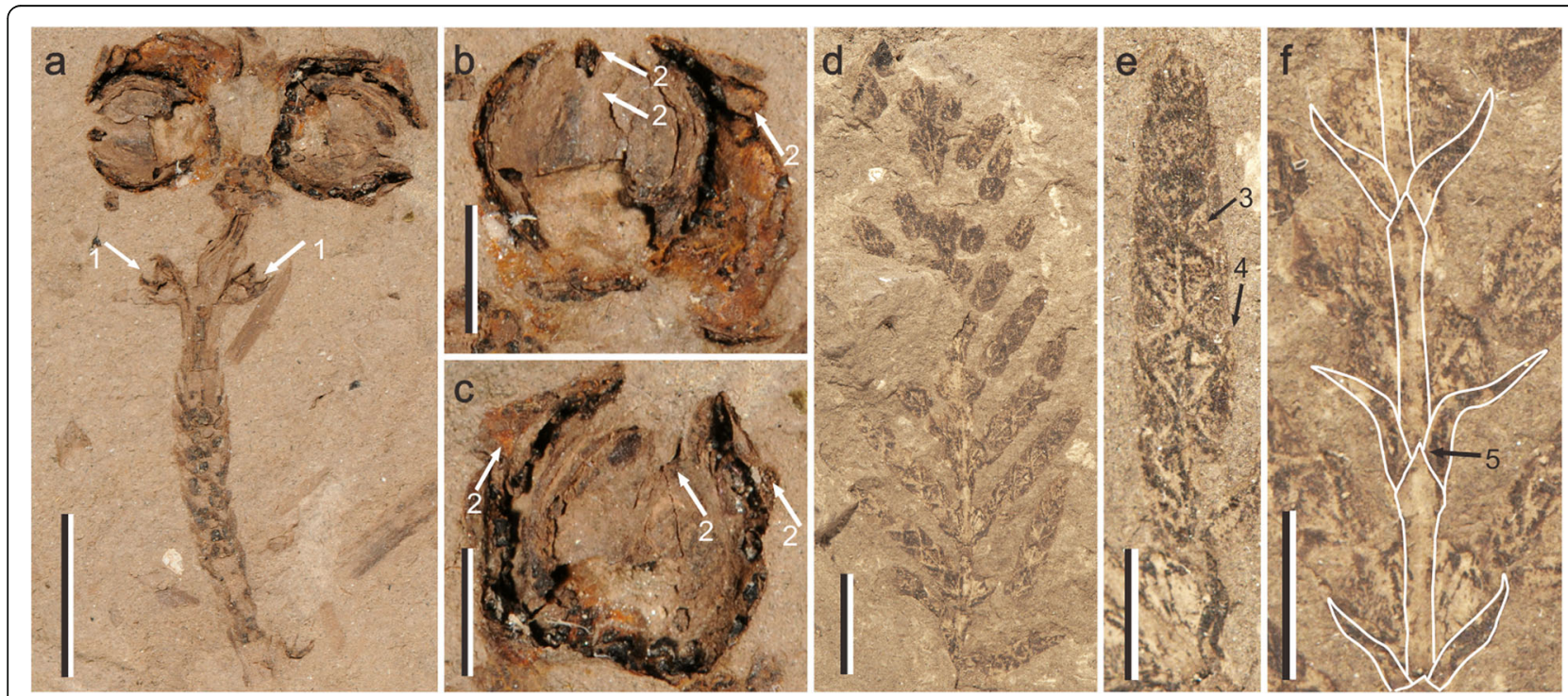

Fig. 1 Morphology of Mesocyparis sinica. (a)-(c) fertile shoot, specimen no. WY0801: (a) seed cones borne in opposite pairs, (arrow 1) two immature seed cones, scale bar = $5 \mathrm{~mm}$; (b) \& (c) two mature seed cones, (arrow 2) umbo of the scale, scale bar = $2 \mathrm{~mm}$; (d) - (f) vegetative shoot, specimen no. WY0802: (d) vegetative shoot, scale bar $=5 \mathrm{~mm}$; (e) branchlets, (arrow 3) the apex of facial leaf, (arrow 4) the apex of lateral leaf, scale bar = $2 \mathrm{~mm}$; (f) branches, (arrow 5) the apex of facial leaf, scale bar $=2 \mathrm{~mm}$ 


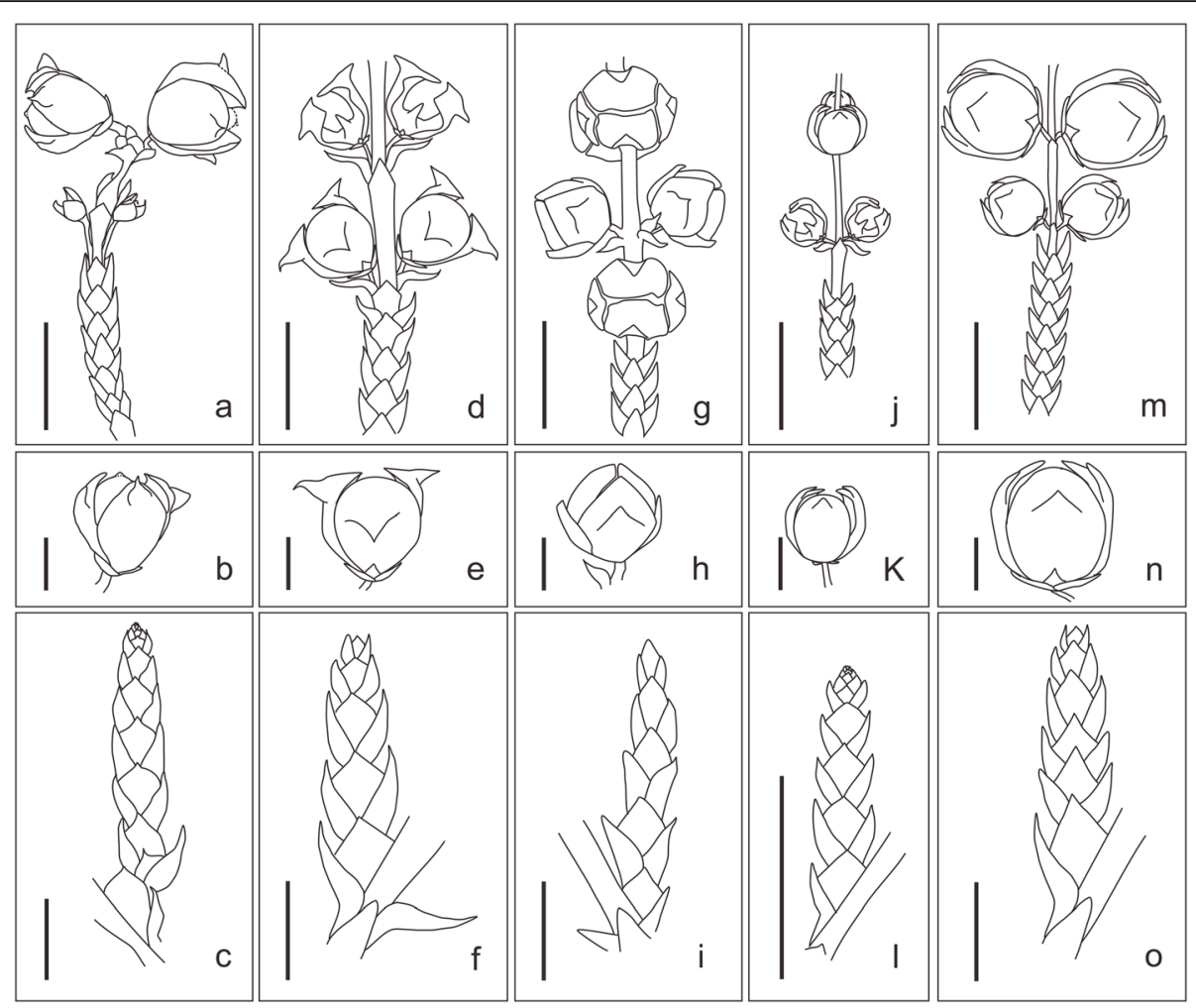

Fig. 2 Line drawing of all 5 species of Mesocyparis. (a), (b) \& (c) M. sinica (this paper); (d), (e) \& (f) M. borealis (redrawn from [18]); (g), (h) \& (i) M.

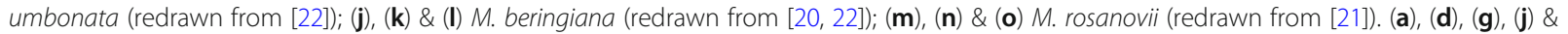
$(\mathbf{m})$ fertile shoot of Mesocyparis, scale bar $=1 \mathrm{~cm} ;(\mathbf{b}),(\mathbf{e}),(\mathbf{h}),(\mathbf{k}) \&(\mathbf{n})$ seed cones of Mesocyparis, scale bar $=2 \mathrm{~mm} ;(\mathbf{c}),(\mathbf{f}),(\mathbf{i}),(\mathbf{I}) \&(\mathbf{o})$ branchlets in vegetative shoots of Mesocyparis, scale bar $=5 \mathrm{~mm}$

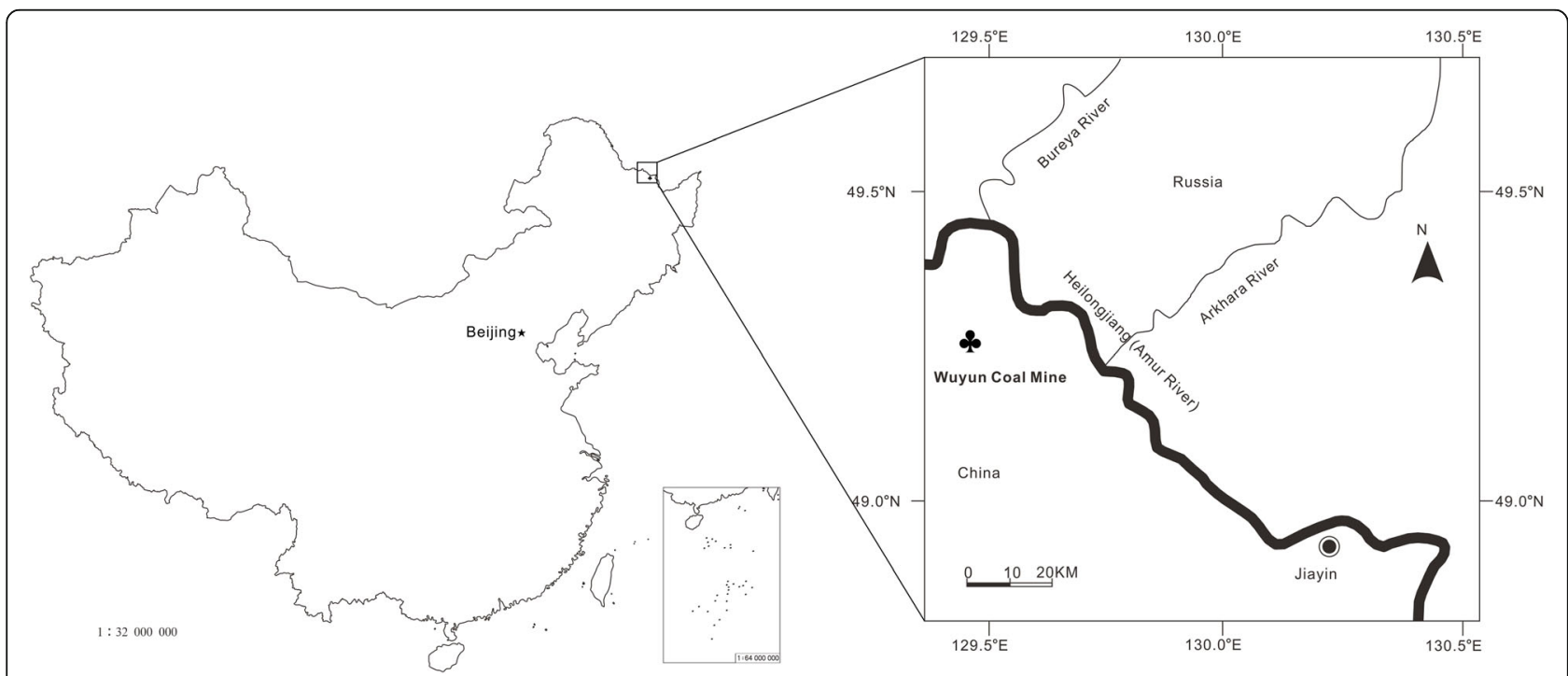

Fig. 3 Locality of Mesocyparis sinica. Map showing the locality ( ) Mesocyparis sinica in Jiayin, Heilongjiang, China. The base map of China Map is quoted from Geographic information systems of China website (http://bzdt.nasg.gov.cn/?ref=qqmap, map number: GS (2016)1570) 
There are some morphological differences between leaves of branches and branchlets (Fig. 1e and f). Facial leaves of branchlets ovate to rhombic, $1.1-2.1 \mathrm{~mm}$ long, $0.8-1.6 \mathrm{~mm}$ wide, adpressed, thickened along midrib, apex acuminate to acute, rising above basal part of subsequent leaves. Lateral leaves of branchlets folded, falcate, $0.9-2.4 \mathrm{~mm}$ long, 0.4$0.8 \mathrm{~mm}$ wide, apex acute; most of them overlap basal part of subsequent lateral leaves (Fig. 1e). Facial leaves of branches $1.8-3.8 \mathrm{~mm}$ long, $0.4-0.6 \mathrm{~mm}$ wide, apex acuminate to acute, thickened slightly, rising slightly above basal part of subsequent leaves. Lateral leaves of branches folded, falcate, $1.7-2.7 \mathrm{~mm}$ long, $0.4-0.5 \mathrm{~mm}$ wide, with apex acute, and basal part covered by earlier facial leaves (Fig. 1f).

\section{Comparison between $M$. sinica and other species of Mesocyparis}

The newly-found fossils from Jiayin and other Mesocyparis records (Figs. 1 and 2) display significant differences (Fig. 2 and Table 1): The seed cones in the Jiayin fossil were erect, with an acuminate apex, while those of $M$. borealis from Saskatchewan, Canada were reflexed, with an acute apex [18]. Seed cones from Jiayin were borne in opposite pairs, with cone scales ovate to obovate, and umbo near the apex of the cone scale, while the leaves of fertile shoots were scaly and dimorphic. In contrast, the seed cones of $M$. umbonata from Alberta, Canada were decussate, with peltate cone scales bearing a central umbo, and leaves of fertile shoots monotypic [22]. The cone scales of the Jiayin specimens are nearly equal in size, while the upper pair of cone scales of $M$. beringiana from Koryak, Russia was larger than the basal pair, while the apex of the umbo was acute. At the same time, the seed cones and foliage of $M$. beringiana were smaller than those of the other three species and the Jiayin fossils [19, 20,22]. Most cone scales of $M$. rosanovii from the Amur Region, Russia were arranged in decussate pairs, only a few being borne in opposite pairs. Moreover, the cone scales were peltate, with an acute umbo apex, and the leaves of the fertile shoots monotypic.

Here we provide a key to the fossil species of Mesocyparis based on cone characters as below:

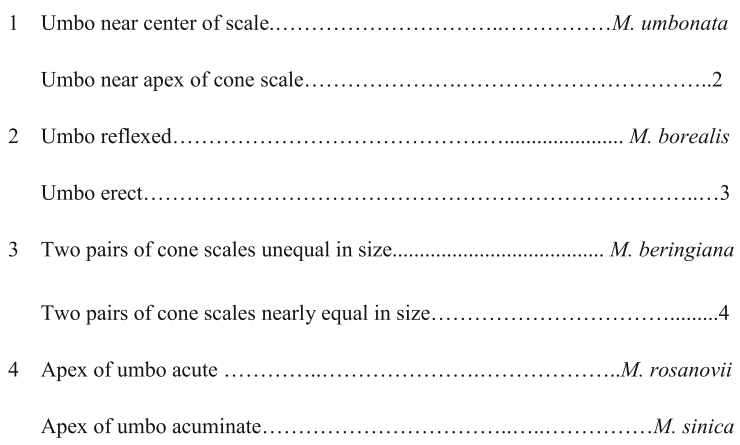

\section{Phylogenetic position of Mesocyparis}

Here we treat the Wuyun fossils as a new species based on a detailed morphological comparison, which shows two or more significant morphological differences between the Wuyun fossils and other Mesocyparis species (Fig. 2, Table 1 and the Key in "Comparison between $M$. sinica and other species of Mesocyparis" section). The full fossil description and a morphological comparison with the other four species in Mesocyparis are provided in supplementary text of the electronic supplementary material.

Our family-wide phylogenetic analysis indicates that Mesocyparis is a member of the Cupressoideae and clusters with Hesperocyparis, Callitropsis-Xanthocyparis, and Juniperus-Cupressus (BS =51\%) (Fig. 4). Mesocyparis shares whorled cone scales equal (Additional file 1: Char. 30:1 and Table S1), and ovule shape obpyriform (Additional file 1: Char. 34:2 and Table S1), with these five genera. The phylogenetic tree of Mesocyparis is shown in Fig. 5, Additional file 2: Figure. S1 and Additional file 3: Table S2. In Mesocyparis, the two western North American species, $M$. borealis and $M$. umbonata, formed a clade (WNA clade, $\mathrm{BS}=70 \%$ ), and the three Asian species, $M$. beringiana, $M$. rosanovii and $M$. sinica, formed another (EA clade, $\mathrm{BS}=65 \%$ ). Mesocyparis sinica is sister to $M$. rosanovii $(\mathrm{BS}=62 \%)$.

\section{Distributional changes during the K-Pg transition}

Paleomaps [23] indicate that the landmasses of Eastern Asia and western North America were connected from the Late Cretaceous to the Paleocene. However, North America in the Late Cretaceous was divided by the Western Interior Seaway, while in the Paleocene western and eastern North America became contiguous due to the retreat of this seaway. Fossil records show Mesocyparis ranged from $59^{\circ} \mathrm{N}-76^{\circ} \mathrm{N}$ paleolatitude (Horseshoe Canyon, Alberta, Canada [18] and Kyoyak, Russia [18-20] during the Late Cretaceous (Fig. 6a) while in the Paleocene it ranged from 52 to $72^{\circ} \mathrm{N}$ paleolatitude (Amur, Russia [21] and Heilongjiang, China (this study) in Asia and Wyoming \& Alaska, USA and Alberta, Canada [22] of western North America) (Fig. 6b). This Mesocyparis distribution (Fig. 6), combined with phylogenetic analysis (Fig. 5), reveals that the genus probably first occurred at high latitudes in the Northern Hemisphere and then divided into 2 clades - - the East Asian (EA) clade and the Western North American (WNA) clade.

\section{Discussion}

\section{Morphological changes during the K-Pg transition}

When plotting the scored 22 morphological characters against the species-level tree of Mesocyparis, we found some significant morphological changes in the genus 
Table 1 Morphological comparison between fossil species of Mesocyparis

\begin{tabular}{|c|c|c|c|c|c|}
\hline Taxa & M. sinica & M. borealis & M. umbonata & M. beringiana & M. rosanovii \\
\hline \multicolumn{6}{|l|}{ Seed Cone } \\
\hline Length (mm) & $4.4-5.2$ & $3.0-5.0$ & $2.8-5.0$ & $2.0-4.0$ & $3.5-5.0$ \\
\hline Width (mm) & $4.0-5.1$ & $3.0-5.0$ & $1.9-4.0$ & $2.0-4.0$ & $3.0-4.0$ \\
\hline Arrangement & opposite & opposite & decussate* & decussate* & $\begin{array}{l}\text { most decussate, } \\
\text { a few opposite* }\end{array}$ \\
\hline \multicolumn{6}{|l|}{ Cone Scale } \\
\hline shape & obovate to ovate & obovate & peltate ${ }^{*}$ & ovate & peltate ${ }^{*}$ \\
\hline Length (mm) & $3.7-4.3$ & $3.0-5.0$ & $2.3-4.0$ & no data & no data \\
\hline Width (mm) & $2.8-3.1$ & 3.0 & $1.8-3.9$ & no data & no data \\
\hline number & 4 & 4 & 4 & 4 & 4 \\
\hline size of the two pairs & $\begin{array}{l}\text { approximately } \\
\text { equal in size }\end{array}$ & $\begin{array}{l}\text { approximately } \\
\text { equal in size }\end{array}$ & $\begin{array}{l}\text { upper pair larger } \\
\text { than lower* }\end{array}$ & $\begin{array}{l}\text { upper pair larger } \\
\text { than lower* }\end{array}$ & $\begin{array}{l}\text { approximately } \\
\text { equal in size }\end{array}$ \\
\hline position of umbo on cone scale & near the apex & near the apex & in center* & near the apex & near the apex \\
\hline Shape of umbo's tip & acuminate & acute* & acute $^{*}$ & acute* & acute* \\
\hline Shape of umbo & erect & reflexed* & erect & erect & erect \\
\hline \multicolumn{6}{|l|}{ Branch } \\
\hline Arrangement & $\begin{array}{l}\text { opposite, forming } \\
\text { flat frond-like sprays }\end{array}$ & $\begin{array}{l}\text { opposite, forming } \\
\text { flat frond-like sprays }\end{array}$ & $\begin{array}{l}\text { more than } 1 / 4 \\
\text { alternate, } \\
\text { others opposite* }\end{array}$ & $\begin{array}{l}\text { opposite, forming } \\
\text { flat frond-like sprays }\end{array}$ & $\begin{array}{l}\text { most opposite, } \\
\text { a few alternate* }\end{array}$ \\
\hline \multicolumn{6}{|l|}{ Leaf } \\
\hline Facia and lateral leaves of fertile shoots & dimorphic & dimorphic & monomorphic* & dimorphic & monomorphic* \\
\hline \multicolumn{6}{|l|}{ Shootlet } \\
\hline Length of facial leaves (mm) & $1.1-2.1$ & $2.0-3.0$ & $0.8-2.0$ & $0.5-0.6$ & 1.5 \\
\hline Width of facial leaves (mm) & $0.8-1.6$ & $1.2-2.0$ & $0.6-1.2$ & no data & 1.0 \\
\hline Length of lateral leaves (mm) & $0.9-2.4$ & $2.0-3.0$ & $0.5-2.0$ & no data & no data \\
\hline Width of lateral leaves (mm) & $0.4-0.8$ & $0.5-1.0$ & $0.1-0.4$ & no data & no data \\
\hline facial leaves overlap & Present & Present & Present & Absent* & Present \\
\hline lateral leaves overlap & Present & Present & Present & Absent* & Present \\
\hline \multicolumn{6}{|l|}{ Shoot } \\
\hline Length of facial leaves (mm) & $1.8-3.8$ & $3.5-6.0$ & $1.4-4.0$ & $2.0-3.0$ & $1.5-3.0$ \\
\hline Width of facial leaves (mm) & $0.4-0.6$ & $0.5-1.0$ & $0.5-0.9$ & $1.5-2.0$ & $0.8-2.0$ \\
\hline Length of lateral leaves (mm) & $1.7-2.7$ & $3.5-5.0$ & $1.5-3.8$ & no data & $1.5-3.0$ \\
\hline Width of lateral leaves (mm) & $0.4-0.5$ & $0.5-1.0$ & $0.2-0.6$ & no data & $0.4-0.8$ \\
\hline facial leaves overlapping & Present & no data & Absent* & no data & Absent* \\
\hline facial leaves appressed & Present & Present & Present & no data & Present \\
\hline lateral leaves overlap & Absent & Absent & Absent & no data & Absent \\
\hline apices of lateral leaves free & Present & Present & Present & no data & Present \\
\hline Location & Heilongjiang, China & $\begin{array}{l}\text { Saskatchewan, } \\
\text { Canada }\end{array}$ & Alberta, Canada & Koryak, Russia & $\begin{array}{l}\text { Amur Region, } \\
\text { Russia }\end{array}$ \\
\hline Age & Early Paleocene & Paleocene & Masstrichtian & Masstrichtian & Early Paleocene \\
\hline Reference & this paper & [18] & [22] & {$[19,20,22]$} & [21] \\
\hline
\end{tabular}

"*" indicating character differences between Mesocyparis sinica and other four Mesocyparis species

from Maastrichtian to Paleocene: 1) seed cones became larger (average cone size increased about 130\%, detail estimates in Methods), 2) the umbo shape on the scale changed from erect (Fig. $2 \mathrm{~h}$ and $\mathrm{k}$ ) to reflexed (Fig. 2e), and 3) the umbo position on the cone scales moved from the middle (Fig. $2 \mathrm{~h}$ and $\mathrm{k}$ ) to the apex (Fig. 2e).

In general, the increasing size of the seed cone in Mesocyparis may be associated with the climate cooling 


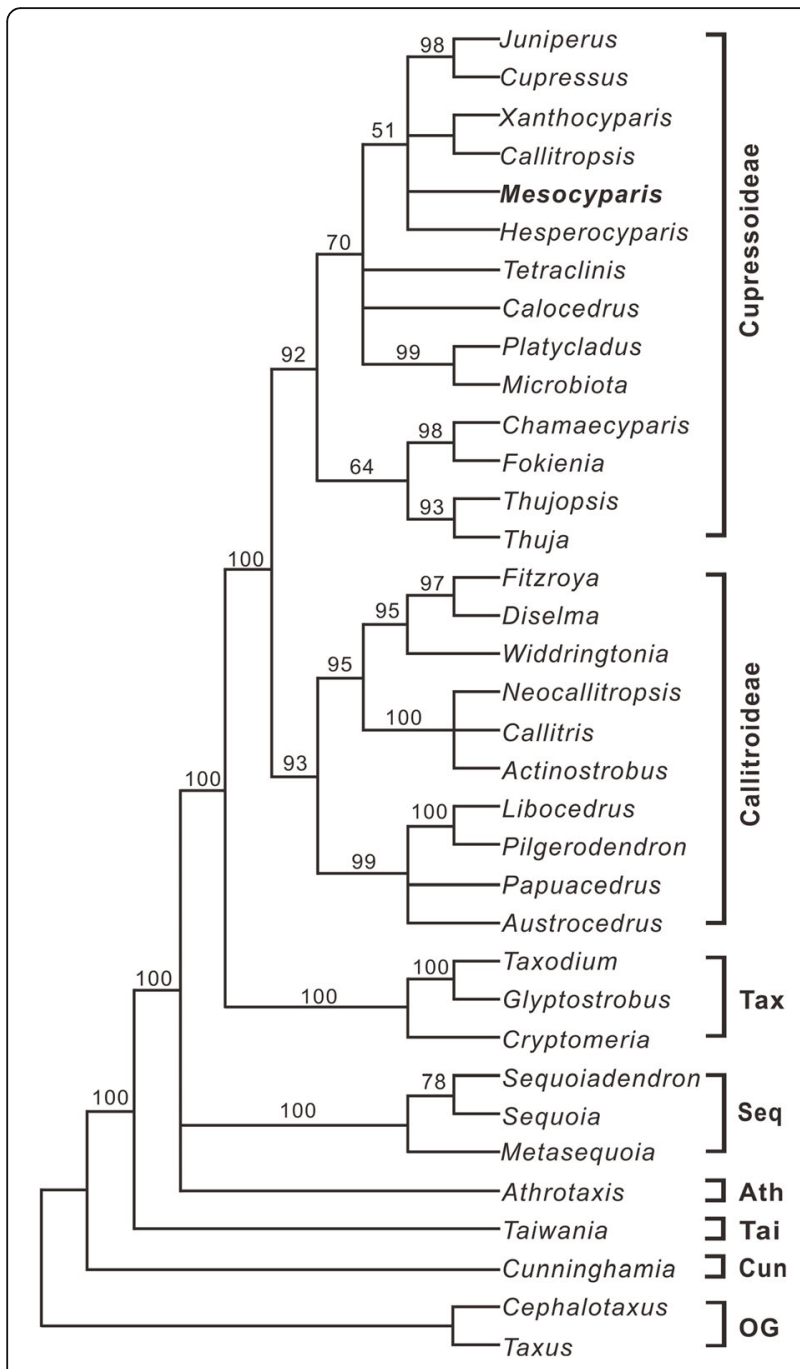

Fig. 4 The strict consensus tree obtained after addition of Mesocyparis (in bold) to the result of the two trees $[48,49]$. Numbers above the branches are bootstrap values (> 50\%). Tax, Taxodioideae; Seq, Sequoioideae; Ath, Athrotaxidoideae; Tai, Taiwanioideae; Cun, Cunninghamioideae; Og, outgroups

from Maastrichtian to Paleocene across the K-Pg boundary. A negative correlation between the cone size and mean annual temperature (MAT) is apparent in modern Cupressus, one of the nearest living relatives of extinct Mesocyparis (Fig. 7 and Additional file 4: Table S3). In addition, it has been observed that fruits and seeds of angiosperms in North America and Europe increased during the K-Pg transition [24].

Specific morphological features can be linked to a specific biological function, and may allow us to speculate about the reason behind Mesocyparis seed cones more than doubling in size across the K-Pg transition. The increasing size of seed cones might augment their visibility and attractiveness for herbivorous and/or omnivorous animals, thereby enhancing seed dispersal, which could expand the plant distribution and increase their ability to survive temporal and spatial environmental change. Today some bird species (such as azure-winged magpie and light-vented bulbul) feed on intact seed cones and we envisage similar feeding strategies existed in early birds during the K-Pg transition. The increasing size of the seed cone might be an adaptive mechanism for seed dispersal (i.e., conspicuously larger seed cones were more attractive for those cone-eating/removal animals). An animal's preference for larger seed cones might select and even amplify the increasing size of seed cones in Mesocyparis. Evidence has shown that the rapid radiation and diversification of birds [25, 26] and mammals [27] that, occurred during this period produced numerous potential vectors for seed dispersal of both gymnosperms and angiosperms.

\section{Cooling during the K-Pg transition drove Mesocyparis southwards}

In general, the geographical distribution of plants at high latitudes is strongly constrained by the terrestrial thermal regime, particularly the mean coldest monthly temperature (MCMT) and/or the mean annual temperature (MAT) $[28,29]$. Thus, the northern limit of a specific terrestrial plant taxon can reflect temperature changes with relatively high sensitivity [30].

The cooling during the K-Pg transition (ca. 70-60 Ma, global average temperature fell by ca. $4{ }^{\circ} \mathrm{C}$ ) [31] could have driven the northern limit of Mesocyparis south by ca. $4^{\circ} \mathrm{N}$ from the Maastrichtian to the Paleocene (Fig. 8 and Additional file 5: Table S4), which means that the northern limit of survival for the plant retreated southwards by ca. $444 \mathrm{~km}$. Similar responses are found in Metasequoia (Cupressaceae) and Nordenskioldia (Trochodendraceae). Metasequoia's northern limit moved south by ca. $4^{\circ}$ (Fig. 8 and Additional file 6: Table S5), while Nordenskioldia's moved almost $5^{\circ}$ (Fig. 8 and Additional file 7: Table S6). These findings indicate that the southward migration of the northern limit of Mesocyparis as driven by the cooling during the K-Pg transition is by no means unique.

\section{Conclusions}

We report a new fossil species, Mesocyparis sinica from the early Paleocene of Jiayin, Heilongjiang, northeastern China. By integrating lines of evidence from phylogeny and the comparative morphology of Mesocyparis, we found that during ca. 70-60 Ma, the size of the seed cone of Mesocyparis increased by ca. $130 \%$, probably driven by the cooling during the K-Pg transition, which might be an effective adaptation for seed dispersal by animals. Meanwhile, our analyses indicate that the northern limits of this genus, as well as those of two other arboreal taxa Metasequoia (gymnosperm) and 


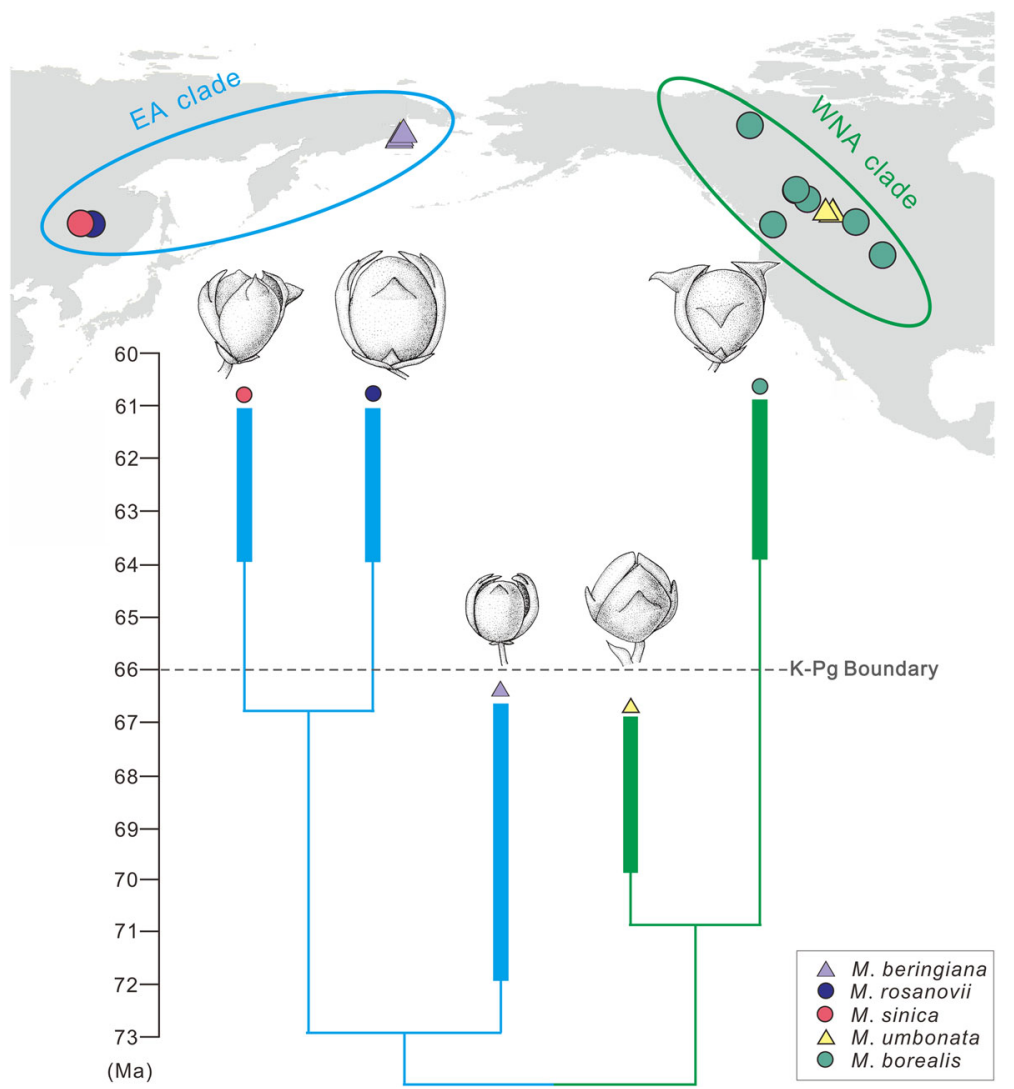

Fig. 5 Time-scaled phylogeny, distribution and seed cone's morphological changes of Mesocyparis. This figure shows obvious morphological changes of Mesocyparis in ca. Ten million years during the K-Pg transition. The cladogram is simplified from the strict consensus tree obtained from the phylogenetic analysis. The bars represent the dating of upper and lower limits of terminal taxon-bearing deposits, and a minimum branch length of 1 Ma based on the "minimum branch length" method used in [53]

Nordenskioldia (angiosperm), have migrated ca. $4-5^{\circ}$ southwards in paleolatitude during this interval, in association with the cooling. This is the first report to link plant evolutionary and ecological responses to the climate cooling during the K-Pg transition. This study not only enriches our understanding of how specific plant taxa responded to the climate changes during the $\mathrm{K}-\mathrm{Pg}$ transition, but also provides a reversed case study for the scientific community to speculate about plant responses and distributional changes under global warming today.

\section{Methods}

\section{Geological setting}

The specimens of Mesocyparis sinica described here were collected from the upper part of the Wuyun Formation, at Wuyun coalmine $\left(49^{\circ} 14^{\prime} \mathrm{N}, 129^{\circ} 28^{\prime} \mathrm{E}\right.$; Fig. 3) in Jiayin County, Heilongjiang Province, NE China. The enclosing sediments of the Jiayin fossil are grey sandy mudstone. Although some authors [32,33] suggested it was of Maastrichtian (Late Cretaceous) age, the Wuyun Formation is now considered to belong to the Danian stage of the Early Paleocene based on palynotology [34-36], vegetation composition [37-40] and stratigraphic correlation [4143]. In addition, Single zircon LA-ICP-MS dating shows the age of the lower part of the Wuyun Formation to be $64.1 \pm 0.7 \mathrm{Ma}[44,45]$.

\section{Materials in this study}

The fossil specimens of Mesocyparis sinica examined in this article are deposited in the National Museum of Plant History of China, Institute of Botany, Chinese Academy of Sciences: WY0801 (Figs. 1a, b and c), WY0802 (Figs. 1d, e and f), WY0803. These specimens were exposed and observed under a stereomicroscope, which identified by Dr. Yi-Ming Cui and Prof. Yu-Fei Wang. The characters were described following the terminology of [46]. Attempts were made to extract structure of seed cones under micro-CT and cuticles of leaf, but these efforts were unsuccessful.

Morphological and distributional information for the other four species of extinct Mesocyparis were collected from literature: $M$. borealis from [18], $M$. umbonata from [22], M. beringiana from [19, 20, 22], and M. rosanovii from [21]. 

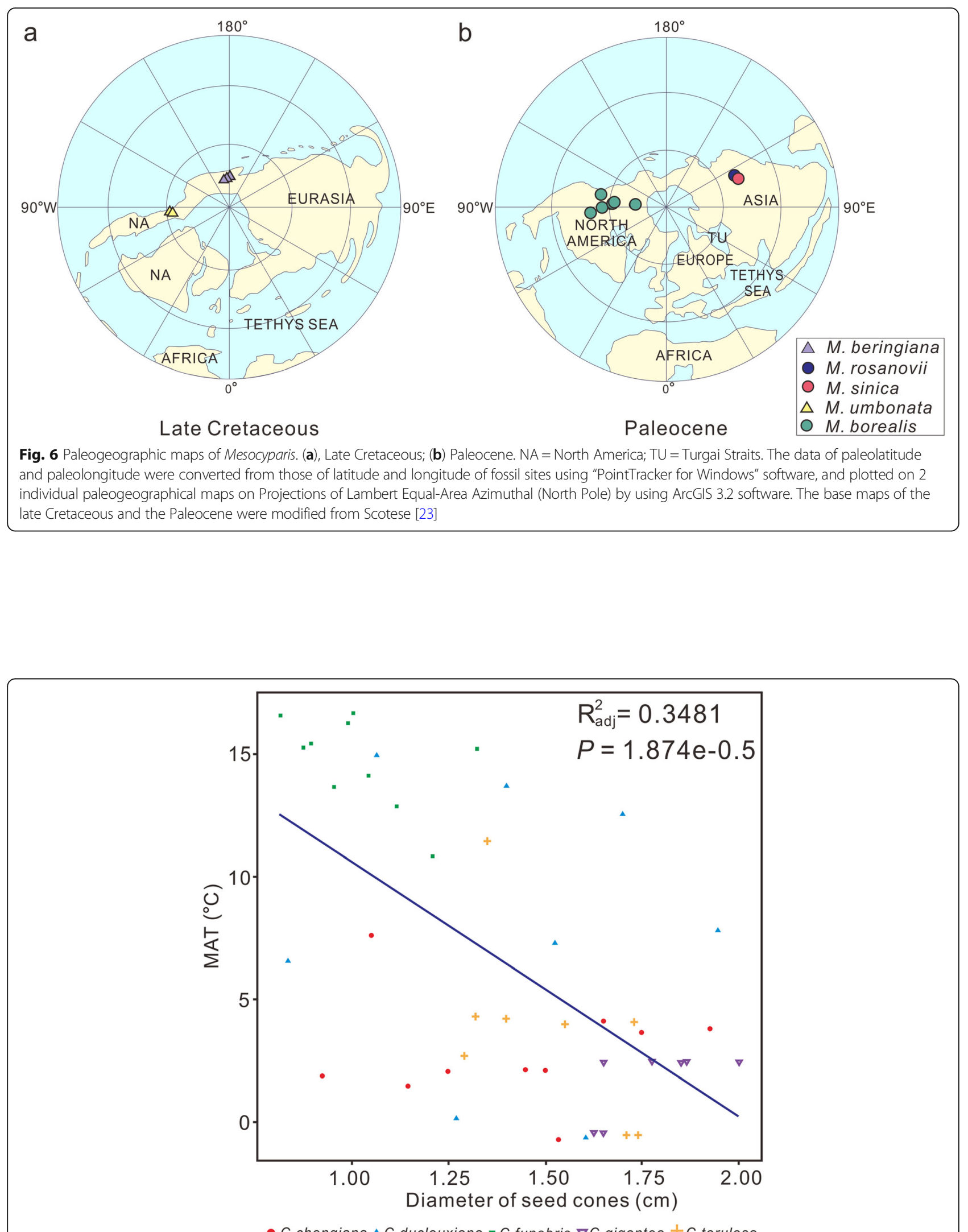

Fig. 7 The relationship between the diameters of the Cupressus cones and mean annual temperature (MAT) 


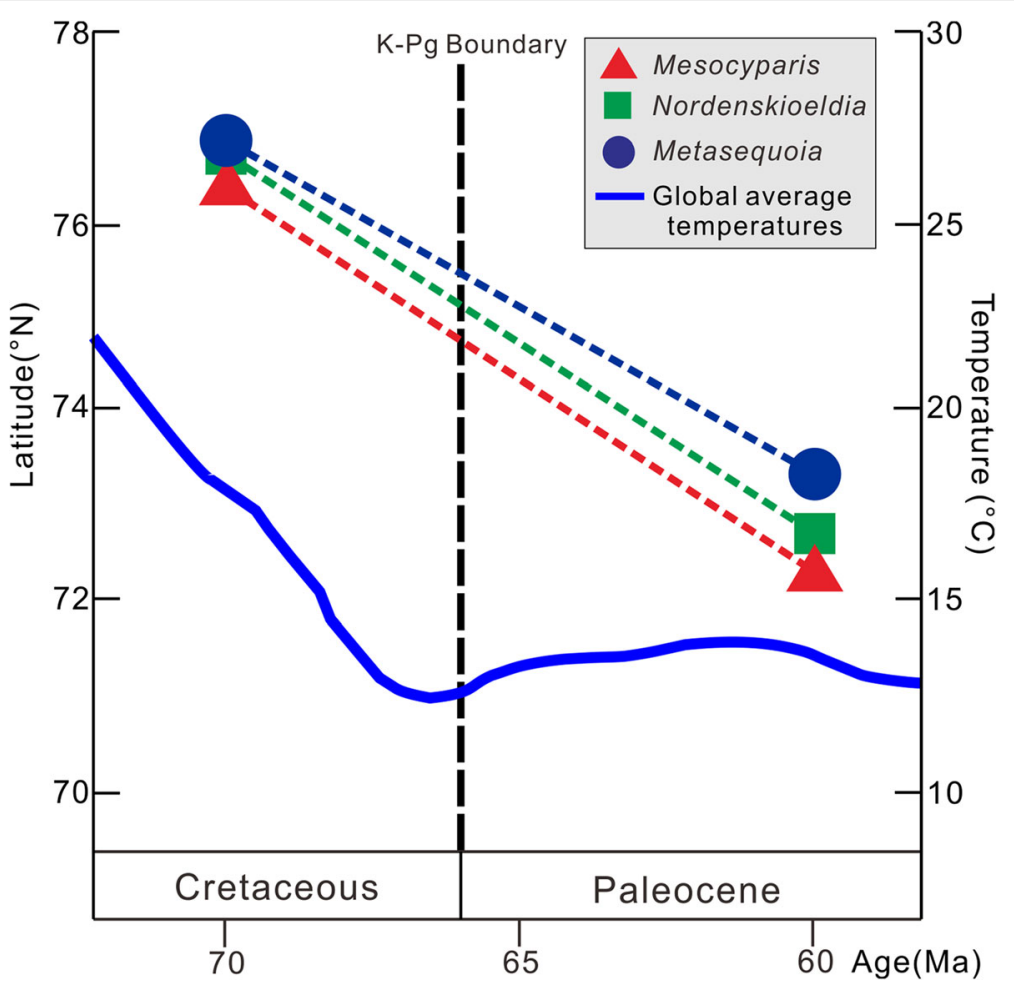

Fig. 8 The paleolatitudinal distribution of Mesocyparis, Metasequoia and Nordenskiodia. This figure shows that the northern limits of these plant taxa migrated southward the cooling during the K-Pg transition. The depiction of global average temperature changes is modified from [31]

The morphological and distributional information of extant Cupressus were measured and collected from specimens in the Herbarium of the Institute of Botany, Chinese Academy of Sciences, Beijing (PE) (Additional file 1: Table S1).

\section{Phylogenetic analysis}

We first used the "backbone constraint" tree approach [47] to determine the phylogenetic position of Mesocyparis in the Cupressaceae s.l. The constrained tree is modified from the two trees of Mao et al. [48] and Yang et al. [49], in which significant conflicting nodes $(\mathrm{BS} \geq 85 \%$ ) between the two trees were collapsed. The morphological matrix was modified from Farjon [46] and included 53 characters (Additional file 1: Table S1). Following the family-wide analysis, we selected Juniperus monticola, Xanthocyparis vietnamensis, and Hesperocyparis arizonica as outgroups and built the species-level relationships of Mesocyparis. All five species of Mesocyparis were included. The 22 morphological characters were coded based on the literature [1822] and our observations (Additional file 3: Table S2). Phylogenetic analysis for each matrix was conducted using maximum parsimony method in PAUP* version $4.0 \mathrm{~b} 10$ [50]. Heuristic searches were performed with 1000 random sequence addition replicates, tree-bisection-reconnection branch swapping, MulTrees in effect, and steepest descent off. Bootstrapping was carried out with 1000 replicates, using a heuristic search strategy.

\section{Estimates of average cone size changes during the K-Pg transition}

Here we use a volume formula of an ellipsoid to estimate the average cone size of each species in Mesocyparis, for the shapes of the seed cones in this genus are ovoid to ellipsoidal. Therefore, we set the seed cone length $(s c l)$ as the polar-radius of the ellipsoid and seed cone width $(s c w)$ as the two equatorial-radii. The estimated volume $(V)$ of Mesocyparis is expressed by the following ellipsoid volume equation:

$$
V=\frac{4}{3} \pi \times \frac{1}{2} s c l \times \frac{1}{2} s c w \times \frac{1}{2} s c w=\frac{\pi}{6} \times s c l \times s c w^{2}
$$

where $s c l=$ median value of seed cone length, $s c w=$ median value of seed cone width. The scls of five species in Mesocyparis are $3.9 \mathrm{~mm}$ (M. umbonata), $3 \mathrm{~mm}$ (M. beringiana), $4 \mathrm{~mm}$ (M. borealis), $4.25 \mathrm{~mm}(M$. rosanovii) and $4.8 \mathrm{~mm}$ (M. sinica), while their scws are $2.95 \mathrm{~mm}$ ( $M$. umbonata), $3 \mathrm{~mm}$ (M. beringiana), $4 \mathrm{~mm}$ (M. borealis), $3.5 \mathrm{~mm}$ (M. rosanovii) and $4.55 \mathrm{~mm}$ (M. sinica). Based on the volume equation, the estimated volumes are 5.657 $\mathrm{mm}^{3}$ (M. umbonata), $4.5 \mathrm{~mm}^{3}$ (M. beringiana), 10.667 $\mathrm{mm}^{3}$ (M. borealis), $8.677 \mathrm{~mm}^{3}$ (M. rosanovii) and 16.562 $\mathrm{mm}^{3}$ (M. sinica). Thus, we can estimate that the average volumes of Mesocyparis in the Maastrichtian and the Paleocene were $5.079 \mathrm{~mm}^{3}$ and $11.969 \mathrm{~mm}^{3}$ respectively, 
so the increase in volume of Mesocyparis from the Maastrichtian to the Paleocene was about 136\%.

\section{Correlational analysis of seed cone sizes of Cupressus and temperature}

To explore the influence of climate change on the morphology of seed cones in Mesocyparis, we calculated the potential relationship between the seed cone sizes of extant Cupressus and temperatures in their habitats. We examined 45 samples of five Cupressus species (C. chengiana S. Y. Hu, C. funebris Endl., C. duclouxiana Hickel, C. torulosa D. Don and C. gigantea Cheng et L. $\mathrm{K} . \mathrm{Fu}$ ) naturally occurring in China from PE Herbarium, which have female cones and entire information on locality and elevation. The diameters of the female cones were measured to represent their seed cone sizes. Mean annual temperature (MAT) used the climate data set of New et al. [51] and then corrected for the altitude of the plant locality using a temperature lapse rate of $5^{\circ} \mathrm{C} / \mathrm{km}$ (Additional file 4: Table S3).

\section{Paleogeographic analysis}

The coordinates of paleolatitude and paleolongitude were compiled from previous reports of Mesocyparis [18-22], Metasequoia (Cupressaceae, gymnosperm) [17] and Nordenskioldia (Trochodendraceae, angiosperm) [52] in the literature, and converted from today's latitude and longitude to those inferred for the Cretaceous and Paleocene using "Point Tracker for windows" software, to plot the sites on paleogeographic maps representing two intervals of geologic time. The base maps with paleocoastlines were modified from paleogeographic maps of the late Cretaceous (ca. 94 $\mathrm{Ma}$ ) and the Paleocene (ca. $60 \mathrm{Ma}$ ) from Scotese [23].

\section{Additional files}

Additional file 1: Table S1. Morphological characters matrix including both extant and extinct species of the Cupressaceae s.l. (DOCX $34 \mathrm{~kb}$ )

Additional file 2: Fig. S1. The strict consensus tree of Mesocyparis inferred from the 22 morphological characters. (TIF $337 \mathrm{~kb}$ )

Additional file 3: Table S2. Morphological characters matrix of Mesocyparis and its outgroups. (DOCX $17 \mathrm{~kb}$ )

Additional file 4: Table S3. The seed cones sizes of Cupressus, their geographic information and mean annual temperature (MAT) of their habitats. (DOCX $19 \mathrm{~kb}$ )

Additional file 5: Table S4. Fossil localities of Mesocyparis and the estimates of their paleo-latitudes and palaeo-longitudes. (DOCX $15 \mathrm{~kb}$ )

Additional file 6: Table S5. Fossil localities of Metasequoia and the estimates of their paleo-latitudes and palaeo-longitudes. (DOCX $20 \mathrm{~kb}$ )

Additional file 7: Table S6. Fossil localities of Nordenskioldia and the estimates of their paleo-latitudes and paleo-longitudes. (DOCX $16 \mathrm{~kb}$ )

\section{Abbreviations}

BS: Bootstrap; ca:: Circa; EA: East Asian; IBCAS: Institute of Botany, Chinese Academy of Sciences; K-Pg: Cretaceous - Paleogene; Ma: Megaannus = Million years ago; MAT: Mean annual temperature; MCMT: Mean coldest monthly temperature; PE: Herbarium of the Institute of Botany, Chinese
Academy of Sciences, Beijing; s.l: Sensu lato; scl: Seed cone length; scw: Seed cone width; V: Volume; WNA: Western North American

\section{Acknowledgments}

We thank Prof. Robert A. Spicer for correcting the manuscript, Prof. Dianne Edwards for reading the previous versions of the manuscript and Ying-Bao Sun for help in drawing the seed cones of Mesocyparis.

\section{Authors' contributions}

YFW conceived research; YMC and YFW identified the fossils; YMC, WW, and JY analyzed the data; while YMC, WW, DKF, JY, and YFW wrote the paper. All authors have read and approved the manuscript.

\section{Funding}

This research was supported by the Strategic Priority Research Program of Chinese Academy of Sciences (No. XDB26000000, XDB310301) for collecting materials, the National Natural Science Foundation of China (No. 31570223, 41790454, 31770231, and 31470315) for doing experiments and analyzing data, the Basic Project of the State Key Laboratory of Palaeobiology and Stratigraphy (20192101) and the Chinese Academy of Sciences President's International Fellowship Initiative (No. 2018VBA0016) for writing and revising the manuscript.

\section{Availability of data and materials}

All data generated or analysed during this study are included in this published article and its additional files.

\section{Ethics approval and consent to participate}

The fossil materials of Mesocyparis sinica used in this study were collected by Prof. Yu-Fei Wang in Jiayin County, Heilongjiang, China. According to both national and local guidelines, there're no specific permissions required for collecting and using the fossils in the study.

\section{Consent for publication}

Not applicable.

\section{Competing interests}

The authors declare that they have no competing interests.

\section{Author details}

'State Key Laboratory of Systematic and Evolutionary Botany, Institute of Botany, Chinese Academy of Sciences, Beijing 100093, China. 'Department of Palaeontology, University of Vienna, Althanstrasse 14, A-1090 Vienna, Austria. ${ }^{3}$ State Key Laboratory of Palaeobiology and Stratigraphy, Nanjing Institute of Geology and Palaeontology, Chinese Academy of Sciences, Nanjing 210008,

China. ${ }^{4}$ University of Chinese Academy of Sciences, Beijing 100049, China.

Received: 27 January 2019 Accepted: 15 August 2019

Published online: 13 September 2019

\section{References}

1. Wilf $\mathrm{P}$, Johnson $\mathrm{KR}$, Huber $\mathrm{BT}$. Correlated terrestrial and marine evidence for global climate changes before mass extinction at the cretaceous-Paleogene boundary. Proc Natl Acad Sci U S A. 2003;100:599-604

2. Li L, Keller G. Variability in late cretaceous climate and deep waters: evidence from stable isotopes. Mar Geol. 1999;161:171-90.

3. Schulte P, Alegret L, Arenillas I, Arz JA, Barton PJ, Bown PR, et al. The Chicxulub asteroid impact and mass extinction at the cretaceous-Paleogene boundary. Science. 2010;327:1214-8.

4. Renne PR, Sprain CJ, Richards MA, Self S, Vanderkluysen L, Pande K. State shift in Deccan volcanism at the cretaceous-Paleogene boundary, possibly induced by impact. Science. 2015;350:76-8.

5. Chiarenza AA, Mannion PD, Lunt DJ, Farnsworth A, Jones LA, Kelland SJ, et al. Ecological niche modelling does not support climatically-driven dinosaur diversity decline before the cretaceous/Paleogene mass extinction. Nat Commun. 2019:10:1091.

6. Chen M, Strömberg CAE, Wilson GP. Assembly of modern mammal community structure driven by late cretaceous dental evolution, rise of flowering plants, and dinosaur demise. Proc Natl Acad Sci. 2019;116:9931-40. 
7. Magallón S, Hilu KW, Quandt D. Land plant evolutionary timeline: gene effects are secondary to fossil constraints in relaxed clock estimation of age and substitution rates. Am J Bot. 2013;100:556-73.

8. Wilson GP, Evans AR, Corfe IJ, Smits PD, Fortelius M, Jernvall J. Adaptive radiation of multituberculate mammals before the extinction of dinosaurs. Nature. 2012:483:457-60

9. Sibert EC, Norris RD. New age of fishes initiated by the cretaceous -Paleogene mass extinction. Proceedings of the National Academy of Sciences, USA. 2015;112:8537-42.

10. Grossnickle DM, Newham E. Therian mammals experience an ecomorphological radiation during the late cretaceous and selective extinction at the K-Pg boundary. Proc R Soc B Biol Sci. 2016;283:20160256.

11. Tschudy RH, Tschudy BD. Extinction and survival of plant life following the cretaceous/tertiary boundary event, Western interior, North America. Geology. 1986;14:667-70.

12. Spicer RA, Collinson ME. Plants and floral change at the cretaceousPaleogene boundary: three decades on. Special Paper of the Geological Society of America. 2014;505:117-32.

13. Wolfe JA, Upchurch GR. Leaf assemblages across the cretaceous-tertiary boundary in the Raton Basin, New Mexico and Colorado. Proceedings of the National Academy of Sciences, USA. 1987:84:5096-100.

14. Bowman VC, Francis JE, Askin RA, Riding JB, Swindles GT. Latest cretaceousearliest Paleogene vegetation and climate change at the high southern latitudes: palynological evidence from Seymour Island, Antarctic peninsula. Palaeogeogr Palaeoclimatol Palaeoecol. 2014;408:26-47.

15. Wolfe JA, Upchurch GR. North American nonmarine climates and vegetation during the late cretaceous. Palaeogeogr Palaeoclimatol Palaeoecol. 1987;61:33-77.

16. Davies-Vollum KS. Early Palaeocene palaeoclimatic inferences from fossil floras of the western interior, USA. Palaeogeogr Palaeoclimatol Palaeoecol. 1997;136:145-64

17. Liu YJ, Arens NC, Li CS. Range change in Metasequoia: relationship to palaeoclimate. Bot J Linn Soc. 2007;154:115-27.

18. Mclver EE, Basinger JF. Mesocyparis borealis gen. Et sp. nov.: fossil Cupressaceae from the early tertiary of Saskatchewan, Canada. Can J Bot. 1987;65:2338-51.

19. Golovneva LB. New genus Microconium (Cupressaceae) from the late cretaceous deposits of the north-east of the USSR. Botanicheskii Zhurnal. 1988:73:1179-83 (in Russian).

20. Moiseeva MG. The Maastrichtian flora of the Amaam lagoon area (northeastern Russia). Stratigr Geol Correl. 2012;20:579-679.

21. Kodrul TM, Tekleva MV, Krassilov VA. A new conifer species, Mesocyparis rosanovii sp. nov. (Cupressaceae, Coniferales), and Transberingian floristic connections. Paleontol J. 2006;40:328-38.

22. Mclver EE, Aulenback KR. Morphology and relationships of Mesocyparis umbonata sp.nov.: fossil Cupressaceae from the late cretaceous of Alberta, Canada. Can J Bot. 1994;72:273-95.

23. Scotese CR. Atlas of earth history. Arlington: PALEOMAP Project; 2001. ISBN: 0-9700020-0-9

24. Eriksson O, Friis EM, Löfgren P. Seed size, fruit size, and dispersal systems in angiosperms from the early cretaceous to the late tertiary. Am Nat. 2000;156:47-58

25. O'Leary MA, Bloch J, Flynn JJ, Gaudin TJ, Giallombardo A, Giannini NP, et al. The placental mammal ancestor and the post-K-Pg radiation of placentals. Science. 2013;341:662-7.

26. Jarvis ED, Mirarab S, Aberer AJ, Li B, Houde P, Li C, et al. Whole-genome analyses resolve early branches in the tree of life of modern birds. Science 2014:346:1320-31.

27. Ksepka DT, Stidham TA, Williamson TE. Early Paleocene landbird supports rapid phylogenetic and morphological diversification of crown birds after the K-Pg mass extinction. Proc Natl Acad Sci U S A. 2017;114:8047-52.

28. Woodward Fl. Climate and Plant Distribution. Cambridge: Cambridge University Press; 1987.

29. Criddle RS, Hopkin MS, Mcarthur ED, Hansen LD. Plant distribution and the temperature coefficient of metabolism. Plant Cell Environ. 1994;17:233-43.

30. Beerling DJ. The impact of temperature on the northern distribution limits of the introduced species Fallopia japonica and Impatiens glandulifera in north-West Europe. J Biogeogr. 1993;20:45-53.

31. Kergoat GJ, Bouchard P, Clamens AL, Abbate JL, Jourdan H, Jabbour-Zahab $R$, et al. Cretaceous environmental changes led to high extinction rates in a hyperdiverse beetle family. BMC Evol Biol. 2014;14:220.
32. Hsu J. Late cretaceous and Cenozoic vegetation in China, emphasizing their connections with North America. Ann Mo Bot Gard. 1983:70:490-508.

33. Tao JR, Xiong XZ. The latest cretaceous flora of Heilongjiang Province and the floristic relationship between East Asia and North America. Acta Phytotaxonomica Sinica. 1986;24:1-15.

34. Markevich VS, Bugdaeva EV, Ashraf AR, Sun G. Boundary of cretaceous and Paleogene continental deposits in Zeya-Bureya Basin, Amur (Heilongjiang) river region. Global Geology. 2011;14:144-59.

35. Markevich V, Bugdaeva E, Nichols D, Sun G. Paleogene coal-forming plants of the Zeya-Bureya Basin (Amur River region). Paleontol J. 2010;44:1321-31.

36. Hao H, Ferguson DK, Feng GP, Ablaev A, Wang YF, Li CS. Early Paleocene vegetation and climate in Jiayin. NE China Climatic Change. 2010;99:547-66.

37. Sun G, Dong ZM, Akhmetiev M, Markevich V, Ashraf AR, Godefroit P, et al. Late Cretaceou-Paleocene biota and the K-Pg boundary, with discussion on extinction of dinosaurs. Shanghai: Shanghai Science and Technology Press; 2014. ISBN:978-7-5428-6111-5.

38. Sun G, Akhmetiev M, Markevich V, Ashraf AR, Bugdaeva E, Godefroit P, et al. Late cretaceous biota and the cretaceous-Paleocene (K-Pg) boundary in Jiayin of Heilongjiang, China. Global Geology. 2011;14:115-43.

39. Sun G, Quan C, Sun CL, Sun YW, Luo KL, Lu JS. Some new knowledge on subdivision and age of Wuyun Formation in Jiayin of Heilongjiang, China. J Jilin Univ (Earth Sci Ed). 2005:35:137-42.

40. Quan C, Sun G, Zhou ZY. A new tertiary Ginkgo (Ginkgoaceae) from the Wuyuan formation of Jiayin, Heilongjiang, northeastern China and its paleoenvironmental implications. Am J Bot. 2010;97:446-57.

41. Wang YF, Li CS, Li ZY, Fu DZ. Wuyunanthus gen. Nova flower of Celastraceae from the Palaeocene of north-East China. Bot J Linn Soc. 2001;136:323-7.

42. Feng GP, Ablaev AG, Wang YF, Li CS. Paleocene Wuyun Flora in Northeast China: Ulmus furcinervis of Ulmaceae. Acta Phytotaxonomica Sinica. 2003;45:146-51.

43. Wang Q, Ablaev AG, Wang YF, Li CS. Paleocene Wuyun flora in Northeast China: Woodwardia bureiensis, Dryopteris sp. and Osmunda sachalinensis. Acta Phytotaxonomica Sinica. 2006:44:712-20.

44. Shigeyuki S, Sun G, Knittel U, Tohru D, Hideki I. Radiometric zircon ages of a tuff sample from the Baishantou member of Wuyun formation, Jiayin: a contribution to the search for the K-T boundary in Heilongjian River area. China Acta Geologica Sinica. 2011:85:1351-8.

45. Knittel U, Suzuki S, Akhmetiev MA, Sun G, Walia M, Hung CH. 66 \pm 1 ma single zircon U-Pb date confirms the location of the non-marine $\mathrm{K}-\mathrm{Pg}$ boundary in the Amur/Heilongjiang River area, (Russia, China). Neues Jahrb Geol Palaontol Abh. 2013;270:1-11.

46. Farjon A. A monograph of Cupressaceae and Sciadopitys. London: RBG Kew; 2000.

47. Endress PK, Doyle JA. Reconstructing the ancestral angiosperm flower and its initial specializations. Am J Bot. 2009;96:22-66.

48. Mao K, Milne Rl, Zhang L, Peng Y, Liu J, Thomas P, et al. Distribution of living Cupressaceae reflects the breakup of Pangea. Proc Natl Acad Sci U S A. 2012;109:7793-8.

49. Yang ZY, Ran JH, Wang XQ. Three genome-based phylogeny of Cupressaceae s.l. : further evidence for the evolution of gymnosperms and southern hemisphere biogeography. Mol Phylogenet Evol. 2012;64:452-70.

50. Swofford DL, PAUP*. Phylogenetic analysis using parsimony (*and other methods), version 4.0b10. Sunderland, MA: Sinauer Associates; 2003.

51. New M, Lister D, Hulme M, Makin I. A high-resolution data set of surface climate over global land areas. Clim Res. 2002:21:1-25.

52. Wang YH, Ferguson DK, Feng GP, Wang YF, Zhilin SG, Li CS, Svetlana PT, Yang J, Ablaev AG. The phytogeography of the extinct angiosperm Nordenskioeldia (Trochodendraceae) and its response to climate changes. Palaeogeogr Palaeoclimatol Palaeoecol. 2009:280:183-92.

53. Wang M, Lloyd GT. Rates of morphological evolution are heterogeneous in early cretaceous birds. Proc R Soc B Biol Sci. 2016:283:20160214.

\section{Publisher's Note}

Springer Nature remains neutral with regard to jurisdictional claims in published maps and institutional affiliations. 